\title{
ANATOMY OF A FAIR-LENDING EXAM: The USES AND LIMITATIONS OF STATISTICS*
}

\author{
Paul S. Calem \\ Board of Governors of the Federal Reserve System \\ Division of Research and Statistics \\ $20^{\text {th }}$ and C Streets \\ Washington, D.C. 20551 \\ pcalem@frb.gov
}

Stanley D. Longhofer

Wichita State University

Barton School of Business

1845 N. Fairmount

Wichita, KS 67260-0077

longhofer@twsu.edu

March, 2000

\begin{abstract}
In this paper, we consider the role of statistical analysis in fair-lending compliance examinations. We present a case study of an actual fair-lending examination of a large mortgage lender, demonstrating how statistical techniques can be a valuable tool in focusing examiner efforts to either uncover illegal discrimination or exonerate an institution so accused. Importantly, our case also highlights the limitations of such statistical techniques. The study suggests that statistical analysis combined with comparative file review offer a balanced and thorough approach to enforcement of fair-lending laws.
\end{abstract}

\footnotetext{
* The views stated here are those of the authors, and do not necessarily reflect those of the Board of Governors of the Federal Reserve System. We thank Robert Avery, Raphael Bostic, Glenn Canner, and Anthony Yezer for helpful comments.
} 


\section{Introduction}

In recent years, statistical analysis has played an increasingly important role in the enforcement of the nation's fair-lending laws. Government agencies that regulate depository institutions, especially the Federal Reserve and the Office of the Comptroller of the Currency, have incorporated statistical techniques into regularly scheduled compliance examinations to help identify possible discriminatory patterns in decisions to grant credit and in the prices of credit. Statistical analysis also has figured prominently in recent fair-lending cases pursued by the Justice Department. Application of statistical techniques to fair-lending enforcement is based on the recognition that isolated instances in which minority applicants appear to have been treated differently than comparable white applicants may reflect purely random outcomes. Statistical testing greatly facilitates the detection of a pattern of discriminatory treatment.

Despite this straightforward rationale, the practice of applying statistical techniques to uncover lending discrimination is somewhat controversial. The logistic regression approach used by compliance examiners is similar to that employed by Munnell et al. $(1992,1996)$ in their well-known study that purported to find evidence of discriminatory treatment of minority applicants by mortgage lenders in the Boston metropolitan area. Since its initial appearance as a working paper at the Federal Reserve Bank of Boston, this study has generated heated debate regarding its validity and proper interpretation. ${ }^{1}$

Critics of this study have questioned whether its results were driven by errors and inconsistencies in the data or by the omission of some important variables from the empirical model. Others have argued that the complex array of factors underlying decisions to approve or deny a mortgage application cannot be adequately represented by logistic regression models. By implication, the use of such statistical models by fair-lending compliance examiners might also appear to be questionable, particularly in light of the substantial commitment of examiner

\footnotetext{
${ }^{1}$ The original paper, Munnell et al. (1992), is commonly referred to as the Federal Reserve Bank of Boston study on lending discrimination. Contributions to the debate include Carr and Megbolugbe (1993), Galster (1993), Tootell (1993), Glennon and Stengel (1994), Yezer, et al. (1994), Browne and Tootell (1995), Rachlis (1995), Sandler and Biran (1995), Bostic (1996), Hunter and Walker (1996), Horne (1997), Day and Leibowitz (1998), and Longhofer and Peters (1999).
} 
resources that statistical modeling requires.

In this paper, we consider the role of statistical analysis within the context of the fairlending examination process as a whole. We present a case study of an actual fair-lending examination of a large mortgage lender, demonstrating how statistical techniques can be a valuable tool in focusing examiner efforts to either uncover illegal discrimination or exonerate an institution so accused. Importantly, the case study also highlights the limitations of such statistical techniques. As we demonstrate, idiosyncratic factors make it extremely difficult to draw definitive conclusions about discrimination from statistical analysis alone. Ultimately, examiners rely on statistical analysis in combination with traditional file reviews and judgmental evaluations.

Indeed, there is an art to performing a fair-lending compliance examination. Although statistical modeling serves as an important tool that brings additional rigor to the process, examiners apply a critical measure of judgment at various stages. The kinds of criticisms directed at the Federal Reserve Bank of Boston study tend to lose their cogency when the full examination context is considered.

Ours is not the first analysis of the use of statistical techniques to evaluate fair-lending compliance. Stengel and Glennon (1999) use data from three exams performed by the Office of the Comptroller of the Currency to demonstrate the importance of using bank-specific underwriting models in these exams. In contrast to their study, however, our emphasis is on the role of statistics within the larger examination context; in particular, how follow-up file reviews shed light on questions raised by the statistical portion of the exam. Thus, our paper is a natural extension of their initial work in this area. Siskin and Cupingood (1996) review the statistical techniques used by the Department of Justice in their investigation of Decatur Federal Savings and Loan, but do not discuss the limitations of such techniques in drawing conclusions about the presence of illegal discrimination. Golan, et al. (1999) use bank exam data to consider the merits of using generalized maximum entropy rather than logistic regression techniques to uncover discriminatory patterns. Once again, however, they do not investigate how these statistical 
techniques would fit into the overall examination process. ${ }^{2}$

In the next section, we briefly review the fair-lending examination process currently used by consumer compliance examiners in the Federal Reserve System for the evaluation of mortgage lending decisions. In Section 3, we introduce our case study of one particular fairlending exam, presenting the statistical results generated for this exam. Section 4 continues the analysis with the matched-pair file review that followed the statistical portion of the exam. In this section, we carefully scrutinize each of the rejected loan files to shed light on the statistical results reported in Section 3. In Section 5, we discuss some of the criticisms of the use of statistical techniques for detecting illegal discrimination, and show how the follow-up file review serves to mute many of these concerns. We conclude and summarize our findings in Section 6.

\section{The Federal Reserve's Examination Process}

Both the Equal Credit Opportunity Act and the Fair Housing Act prohibit mortgage discrimination on the basis of a number of protected characteristics, including race and ethnic status. ${ }^{3}$ The federal bank supervisory agencies are responsible for enforcing these laws with respect to their regulated depository institutions. For the Federal Reserve System, this responsibility covers state member banks and their subsidiaries. If the bank regulatory agency uncovers specific and credible evidence of discrimination, it is required by law to refer the suspect institution to the Department of Justice for further investigation and possible prosecution.

Within the Federal Reserve System, the fair-lending examination process, as it pertains to mortgage credit-granting decisions, combines examiner judgment with statistical methods and involves a number of steps. The full process is discussed in detail in Calem and Canner (1995). As a review, we briefly describe each of the steps in turn. ${ }^{4}$

\footnotetext{
${ }^{2}$ Rosenblatt (1997) also looks at data from a single mortgage bank, with particular attention to whether applicants correctly self-select into the proper loan program (conventional vs. FHA/VA). He does not, however, directly focus on the use of statistical techniques as a tool for fair-lending enforcement.

${ }^{3}$ Other protected characteristics include gender, age, marital status, familial status, religion, national origin, receipt of public assistance, and handicap; the specific prohibitions differ slightly between the two acts.

${ }^{4}$ Similar procedures generally are followed for the fair-lending evaluation of pricing decisions. Examiners perform an initial review of pricing, and if this yields evidence of disparities, detailed statistical analysis would be undertaken.
} 


\subsection{HMDA Review}

The data requirements for a full-scale logistic regression analysis of a bank's lending practices are substantial, making such an analysis a costly endeavor for both the bank and the regulatory agency. In order to limit such investigations only to those cases that are most likely to uncover discriminatory treatment, examiners run an initial statistical analysis of a bank's lending activity using data made available through the Home Mortgage Disclosure Act (HMDA). This process is known internally within the Federal Reserve as "step one." The computer program that implements step one can be run with data readily available in an electronic format, making it a low-cost procedure. Furthermore, this program can be run well in advance of when the examiners conduct their on-site review of the institution's activities, allowing them to plan their on-site time more effectively. ${ }^{5}$

Essentially, the step-one program first sorts an institution's mortgage loan applications by product type (conventional home purchase, FHA or VA home purchase, conventional refinance, FHA or VA refinance, and home improvement), number of applicants (one or more-than-one), the market or metropolitan statistical area (MSA), action date, and applicant race. ${ }^{6}$ Each minority application is then matched to all non-minority applications filed for the same product, same market, same calendar quarter of action date (for large institutions), with the same number of applicants (single or joint), and similar income and loan amount. The disposition of the minority application (approved or denied) is then compared with the average disposition of all non-minority applications matched to it. This comparison is averaged over all minority applications for the institution as a whole and within each of the institution's product and product/market cells. $^{7}$

Examiners use the statistics generated by the step-one program to determine whether a full-blown logistic analysis appears warranted and to help select a product category and market area on which to focus if it is. Often, however, these decisions are not based solely on statistics nor arrived at mechanically. Rather, contextual factors are considered and judgment comes into

\footnotetext{
${ }^{5}$ The following description of the step one procedure is adapted from Avery, Beeson, and Calem (1997), where econometric issues pertaining to this procedure also are discussed.

${ }_{7}^{6}$ Attention is restricted to loans pertaining to 1-4 family properties.

${ }^{7}$ Minority applications that cannot be matched to any non-minority application are not included in the analysis.
} 
play.

The decision whether to proceed with a more-detailed statistical analysis begins with an evaluation of the matched-pair disparities. First, a product or product/market cell must exhibit a disparity that is statistically significant, preferably at the 5 percent level or higher to qualify for further statistical review. Also critical is the economic significance of these disparities. Experience with full-blown regression analysis has shown that small denial-rate disparities in the HMDA data usually disappear once other factors such as loan-to-value ratios, debt obligation ratios, and applicant credit histories are taken into account. Typically, cases involving small disparities are not subject to further statistical review.

Moreover, isolated disparities within individual product/market cells may not be viewed as worth investigating if there is no statistically significant disparity at the aggregate product level. In particular, for a large institution that operates in many markets, a particularly large disparity in one market may reflect randomness in the distribution of denials across markets (that might produce a "false positive" indication of potential discrimination). Examiners must weigh this possibility against the potential for discrimination to be a localized phenomenon reflecting, for example, the activities of a rogue loan officer or decisions made in response to particular market conditions. ${ }^{8}$ One factor that would be taken into account is the degree to which underwriting decisions are centralized.

The size and composition of the potential sample of loan applications are also critical considerations. Ideally, a targeted product or product/market category would contain at least 100 minority applicants (to be matched with at least 100 white applicants.) Smaller numbers may be used if the statistical significance and the magnitude of the disparity are large. The potential sample must also contain an adequate mix of approved and denied applications and an adequate mix of applications from minorities and non-minorities. ${ }^{9}$ Further, examiners generally will not proceed with further statistical analysis if the category under consideration is expected to be too

\footnotetext{
${ }^{8}$ Some observers have raised concerns that examiners do not give adequate weight to the possibility of "false positives."

${ }^{9}$ For instance, examiners will not pursue cases where the sample would contain fewer than 10 rejected applications from non-minorities. Alternative statistical procedures for addressing situations in which the denial-rate disparity is large but the denial rate for non-minorities is very low are under development.
} 
heterogeneous with respect to the combination of loan types contained therein. ${ }^{10}$ Another issue that commonly must be dealt with is the extent to which it is appropriate to pool samples from different markets or years.

In cases where the institution has multiple products or market areas qualifying for further statistical review, judgment frequently is required to determine which to select for further analysis. Categories exhibiting a larger disparity and providing a larger and more homogeneous sample tend to be favored, but other factors, such as the degree to which underwriting is centralized, findings from prior examinations, and complaints from the public are considered.

It is important to note that the primary purpose of the step-one procedure is to provide an initial screen on the data. In effect, this program is used to conserve examiner resources by screening out cases in which a full regression analysis would be unlikely to uncover any illegal disparities even if it were performed. Importantly, no conclusions are ever drawn based solely on the step-one analysis. Even if the step-one analysis does not indicate a full-blown regression is appropriate, examiners may still use the matched applicant pairs generated by the program to conduct a more-traditional comparative file review.

\subsection{Sample Selection and Data Collection}

If it is determined that a full-scale regression analysis is necessary, the next stage is to identify specific loan files to pull for the sample. A slightly modified version of the matchedpair process used for the initial screening is employed to draw the sample. Each minority applicant within the targeted product or market/product cell is paired with its closest nonminority applicants, where up to three matches are allowed. ${ }^{11}$ A random sample of pairs is taken if the number of minorities is too large for the resources at hand. Otherwise, each of the minority applicants is included in the sample, along with at least one of its matched non-minorities.

It then becomes the examiners' job to determine which data items to collect from these files. Although there are standard variables that are always collected for these examinations,

\footnotetext{
${ }^{10}$ Any of the broadly delineated product categories in HMDA data may encompass distinct loan products. For example, the home improvement category often includes secured and unsecured term loans as well as home equity lines of credit.

${ }^{11}$ Matches are selected with replacement, meaning that the same non-minority can be matched to several minorities.
} 
examiners must nevertheless use their knowledge of the bank's underwriting practices to augment this list. Most relevant to determining which variables to collect is the information examiners learn from discussions with the institution's loan officers and underwriting committee and from a review of written lending policies. Variables the institution claims to use in its underwriting process are important to include in a full regression analysis of the institution's underwriting practices.

These discussions also give examiners an opportunity to verify that the underwriting "model" used by the institution does not inherently violate fair lending statutes. For example, if a bank claimed to consider an applicant's marital status, this would likely constitute a referable violation.

Once the variables to be collected have been determined, examiners then begin the painstaking task of collecting data from the files selected for the sample. During this process, substitute loan files may be selected if HMDA coding errors and files with missing data are uncovered. In the end, examiners collect detailed information from between 100 and 500 loan applications that will be used in the next stage of the process.

\subsection{Logistic Regression Analysis}

Logistic regression techniques are then used to evaluate these data. This detailed statistical analysis is known internally within the Federal Reserve as "step two." As with the Federal Reserve Bank of Boston study, the goal of the step-two analysis is to determine whether applicant race (or some other protected characteristic) appears to be systematically related to the lender's decision to accept or reject an application, after controlling for legitimate underwriting factors.

The initial model specification is based on the examiners' review of the institution's underwriting policies, but additional specifications are tested as well. In particular, different definitions of acceptable loan-to-value ratios, obligation ratios, and "severe" credit defects are tested to see which best explains the bank's underwriting practices. If the sample is drawn from more than one market, differing market conditions that may affect denial rates are controlled for 
by means of market-specific dummy variables, regardless of whether market-specific factors are explicitly recognized in the lender's stated underwriting policies. Similarly, variables are included to control for other potential sources of heterogeneity, such as whether the application was for a loan with a fixed or an adjustable interest rate, or whether it was processed by a broker or an in-house loan officer.

\subsection{Comparative File Review}

Regardless of its outcome, examiners follow the step-two procedure with a detailed review of loan files. The computer program used to implement the step-two statistical analysis uses the final (most-preferred) model specification to pair rejected applications with approved ones that appear to be less qualified than the rejected file in question. Examiners carefully inspect these rejected applications and compare them to those that were approved, noting any special circumstances that were not included in the original regression analysis. They may also examine individual applications not included in such pairs, seeking additional insight into factors that may affect the disposition of a loan application.

If the regression analysis indicates a statistically significant disparity between white and minority applicants, examiners use the follow-up review to confirm or refute this initial indication of illegal discrimination. By looking directly at the loan files, examiners can ascertain the true source of the disparity. As we will see in the case study below, information uncovered in this step of the examination will often explain the credit decision and indicate the applicant's race or ethnicity played no role.

At the same time, however, the matched-pair analysis can uncover illegal acts that may have gone undetected by a purely statistical review. For example, hand-written notations by loan officers found in the loan file may cause examiners to ask further questions about the bank's underwriting practices or the actions of a particular employee. Thus, even when the initial statistical analysis does not reveal a statistically significant race effect, the matched-file review is an essential element of a comprehensive fair-lending investigation. 


\section{A Case Study of a Fair-lending Exam}

To better understand the role of statistical analysis in fair-lending compliance examinations, we review an examination recently performed by Federal Reserve staff. The subject of the examination was a large institution with a presence in several geographic markets. Although we focus on a single examination, it is important to note that the steps followed in this exam — and the ultimate conclusions that resulted—are quite typical. Thus, this exam provides an excellent illustration of the uses and limitations of statistics in the fair-lending examination process.

\subsection{Initial HMDA Analysis}

As discussed above, the step-one procedure compares minority and white loan applications to find relatively close matches based on the information available through HMDA. The procedure then evaluates denial-rate disparities between the matched minorities and whites at the aggregate institution level and within product and product/market cells.

Selected output from this analysis is reproduced in Table $1 .{ }^{12}$ The columns in this table show the denial rates for paired white and minority applicants and the resulting denial-rate disparity, both for the institution as a whole and within each product classification. ${ }^{13}$ Overall, minority applicants at this financial institution during the year under review were roughly 50 percent more likely to be denied loans than were white applicants. Similar disparities existed across all loan product categories. ${ }^{14}$

Table 2 shows the breakdown of denial rates based on the race of the applicant. As is often the case, the relatively small number of American Indian loan applications makes statistical analysis impossible, despite their comparatively high matched denial rate. Although the number of Asian applicants at this bank was sufficient to permit a statistical analysis, the size of the

\footnotetext{
${ }^{12}$ More information is contained in the step-one reports than is reproduced here. The data presented were chosen to reflect the salient issues in this exam, while protecting the identity of the financial institution in question.

${ }^{13}$ In the initial step-one analysis, an applicant is classified as a minority if either the applicant or the co-applicant is listed as being non-white in the HMDA data (HMDA race codes 1, 2, 3, 4, or 6). HMDA codes 7 and 8 (Not Provided and N/A, respectively) are excluded from the analysis.

${ }^{14}$ The large disparity among FHA/VA refinancings was only significant at the $10 \%$ level, due to relatively few loan applications in this product class.
} 
disparity for this group was relatively small and lacking in any statistical significance. This, too, is quite typical. In contrast, Black applicants were 1.8 times more likely to be rejected than matched whites, while Hispanic applicants faced a denial-rate disparity of 1.25 to 1 , both of which were statistically significant at the $1 \%$ level.

The step-one program also allows examiners to separately evaluate the lending activity in each MSA in which the bank does business. Table 3 shows the matched-pair denial-rate disparities within the particular MSA on which examiners ultimately chose to focus their efforts. $^{15}$ As can be seen in the table, the overall paired denial-rate disparity in this market was comparable to that for the institution as a whole (1.5 to 1$)$. Within this market, the conventional purchase loan category exhibited a paired denial-rate gap of more than 2 to 1 .

Based on the information summarized in these tables and other factors, examiners decided to collect data to perform a full logistic regression on the institution's conventional home purchase lending activity in this MSA. Although the paired denial-rate disparity was relatively modest in magnitude (under 10 percentage points), the decision to proceed was based on a number of considerations, including the fact that this institution had not previously been subject to a detailed statistical fair-lending review.

\subsection{Data Collection}

Using the sample-selection procedure described earlier, 420 conventional home purchase mortgage application files were selected for the full regression analysis. In the end, 10 of these files were removed from the sample because of coding errors in the HMDA data (e.g., they belonged to a different product category) or because the bank was unable to locate the loan files requested. An additional 70 loan files were excluded because they were applications for a special loan program with different underwriting criteria. ${ }^{16}$ This left a final sample of 340 loan files, including 43 denied applications. The number of applications from minorities was 154, of

\footnotetext{
${ }^{15}$ All of the MSAs that this institution served were reviewed in a similar way. This MSA was chosen for the steptwo analysis based on a number of factors, including presence of a large number of minorities and the fact that the disparity in this MSA was typical for that of the institution as a whole.

16 Examiners performed a detailed analysis of these loans, using both statistical techniques and judgmental file review, and found no evidence of illegal discrimination among these loans.
} 
which 30 were denied. ${ }^{17}$

In total, examiners collected 72 data items (including information reported under HMDA), which were then used to create literally dozens of additional variables for the logistic regression analysis. The data collected included personal information about the applicant and co-applicant (e.g., race, gender, income, assets, housing expenses, employment history, credit history, and bankruptcies and foreclosures); characteristics of the requested loan (e.g., principal and interest payments, whether mortgage insurance was obtained, the application and action dates on the loan, and the loan officer processing the application); and information about the subject property (e.g., its appraised value and the census tract in which it was located).

\subsection{Statistical Analysis}

Because our goal is to contribute to a general understanding of the role of statistical analysis within the overall context of a fair-lending compliance evaluation, we do not present all of the various model specifications that were investigated in the course of this examination. Suffice it to say that dozens of different specifications were tried, with particular consideration of the most effective controls for the applicant's credit history. The final specification was chosen to include variables that best captured the impact of the applicant's credit history, income, and property as these related to the institution's credit-granting decisions. Importantly, these variables were subjected to a number of robustness checks, and their predictive power remained quite strong in response to changes in other variables included in the model.

The final variables used in the analysis are listed and defined in Table 4. Several points are worth noting about the variables selected for the regression. First, although examiners collected detailed information about the number and type of delinquencies shown on the credit report, by far the best predictor of loan acceptance was the bankruptcy variable ultimately selected. This was consistent with the bank's stated underwriting policy, under which minor delinquencies were not weighed very heavily. Similarly, several specifications for obligation ratios were considered, including both continuous and discrete versions. In the end, back-end

\footnotetext{
${ }^{17}$ For this product/market category, the matched-pair denial-rate disparity did not vary much in magnitude with the racial or ethnic classification of the minority applicant. Therefore, all minority groups were included in the analysis.
} 
(total debt payment-to-income) ratio bounds of $40 \%$ and $45 \%$ proved to be the most descriptive of the bank's actual underwriting practices; the front-end (housing debt payment-to-income) ratio did not appear to matter after controlling for the back-end ratio. Third, the size of the loan did not appear to affect its likelihood of being approved once the loan-to-value (LTV) ratio was considered. At the same time, higher LTV cutoffs such as $90 \%$ and $95 \%$ had little explanatory power above that provided by identifying loans with LTV ratios above $80 \%$. Finally, the model controlled for potential seasonal variation in the bank's lending activity. Applications received in the spring and summer-when application volume is typically high-may receive less attention by an underwriter or loan officer. For example, individuals who apply during peak periods may have less opportunity to explain weaknesses in their credit record or employment history. Consequently, these applications may be more likely to be rejected than those received in the fall or winter.

Descriptive statistics for the variables used are presented in Table 5. Overall, 87 percent of all mortgage loan applications in our sample were approved. Some other notable features of the sample are: $48 \%$ of the applications were forwarded by a broker rather than by an in-house loan officer; $24 \%$ of the applications had a bankruptcy, collection, judgement, or foreclosure on the credit report; and $45 \%$ of the sample was comprised of minority applicants.

Logistic regression results are reported in Table $6 .{ }^{18}$ All of the variables included in the final specification are statistically significant, with the exception of the co-applicant dummy variable, applicant income, and a dummy variable for applications in the $1^{\text {st }}$ quarter of the year. Most variables are significant at the 1 percent level or higher. The percentage point impacts are derived by calculating the probability of approval for an applicant with the mean income $(\$ 47,956)$ and for whom all dummy variables are equal zero, and comparing this probability with that of an applicant who is identical in every respect except the characteristic in question. For dummy variables, this means setting the variable in question equal to 1 , and for income it involves increasing the applicant's income by $\$ 1,000$. To clarify the interpretation of this

\footnotetext{
${ }^{18}$ The results reported are for a non-weighted regression. The results were essentially unchanged when the equation was re-estimated after assigning weights consistent with the matched-pair procedure used to draw the sample. For that estimation, the weight assigned to a particular white applicant was based on the number of minorities with which the applicant was paired and on the total number of whites matching to these same minorities.
} 
number, note that the probability that this hypothetical "normal" applicant is approved is 97.38\%. In contrast, an applicant whose liquid assets (at the time of application) are below those required for closing $($ Deficit $=1)$ but is "normal" in every other respect has a $91.58 \%$ chance of being approved. ${ }^{19}$

Of primary interest from an examination standpoint is the minority dummy variable. This coefficient is statistically significant at the $2 \%$ level. At first glance, the 4.56 percentage point impact for minority approvals may not seem particularly large. But given that the base case denial rate is only $2.62 \%$, this translates into a 2.8 to 1 denial-rate disparity. More strikingly, when other derogatory factors are present, the impact of minority status increases dramatically. For example, a "normal" white applicant with a LTV ratio above $80 \%$ is approved $92.81 \%$ of the time. In contrast, an otherwise identical minority has only an $81.45 \%$ chance of approval. A disparity of this magnitude will generally merit close scrutiny by examiners.

The next step in the examination process is to investigate credit decisions more closely by reviewing matched files. As we will see, this review often reveals legitimate explanations for the disparities uncovered by the statistical portion of the exam.

\section{Follow-Up File Review}

Using the predictions based on the estimated equation along with selected characteristics for matching, the step-two program generates new pairs of rejected and approved loan applications on which examiners can focus their efforts. The rejected application in each pair has an equal or greater predicted likelihood approval than the approved application (after accounting for the predicted effect of race.) Examiners carefully inspect each of these loan files and possibly other files as well, taking detailed notes about information revealed in these files that may have been omitted from or not adequately accounted for in the statistical analysis. Each rejected loan application was included in the follow-up review for the institution that is the subject of our case study.

\footnotetext{
${ }^{19}$ Applications exhibiting such a funding deficit are not necessarily rejected because the applicants may be able to demonstrate alternative sources of funds, such as investments they plan to liquidate or gifts from close relatives.
} 
In this section, we review the findings from this stage of the examination. The primary reasons behind the denial of each of the rejected loan applications are summarized in Table 7. The information gleaned from the follow-up review indicated that most rejections occurred at least in part for legitimate reasons that cannot be effectively controlled for using statistical techniques. Therefore, examiners concluded that there was no evidence of illegal discrimination.

\subsection{Unverifiable Information or Incomplete Application}

Nearly half of all rejected applications (20 out of 43) were denied primarily because of unverifiable information (such as reported income) or incompleteness. Nearly all (12 out of 14) brokered applications and about a quarter of (8 out of 29) direct applications that were rejected had unverifiable information or were incomplete. Table 8 shows the results of a logistic regression in which applications that were rejected for reasons other than incompleteness or unverifiable information were excluded from the analysis. ${ }^{20}$ As evidenced in this table, when we restricted our attention only to denials for unverifiable information or incompleteness, we found a statistically significant disparity between the minority and white denial rates. The overall disparity was driven by the brokered application denial rates. ${ }^{21}$

Denial-rate disparities arising because of unverified or incomplete information in the loan file can be a particular concern from a fair-lending perspective, because such disparities may reflect disparate treatment by the loan officers and others who collect this information. For example, if underwriters have been less aggressive in verifying the income and assets of minority applicants, then this type of disparity would result. Although statistical analysis can help identify this as an issue for examiners to address, it is an inappropriate tool for determining whether there actually was bias in the bank's efforts to obtain or verify information. Instead, this issue can only be evaluated judgmentally by examiners.

It is noteworthy that the source of this disparity was loans originally solicited by a broker.

\footnotetext{
${ }^{20}$ The specification in this regression is more parsimonious than that shown above because the smaller number of rejected loan files reduces the power of the statistical tests. The results were robust to performing a multinomial logistic regression incorporating each of the possible outcomes: approvals, denials due to unverifiable information or incompleteness, and other denials.

${ }^{21}$ This was confirmed by re-estimating the equation with interaction terms differentiating among brokered and direct applications from whites and minorities.
} 
Brokered loans are substantially less likely to be rejected than loans coming from in-house loan officers. This fact suggests that a broker is unlikely to submit a loan package to this bank if he or she believes this application will not meet the bank's underwriting guidelines. At the same time, brokers know that the bank will diligently verify the information contained on the application, making the broker's verification efforts redundant. Thus, when brokered loans are rejected, it is rarely because the applicant fails to meet the bank's underwriting guidelines, but rather because the information contained in the loan file could not be verified.

In the end, examiners found no cause for concern regarding the collection and verification of information by this institution. In particular, there was no evidence to suggest that time spent by the bank on minority files that were rejected for this reason differed from that spent on white files rejected for the same reason (Table 9). ${ }^{22}$

\subsection{Omitted variables or Idiosyncratic Factors}

When applications denied due to unverifiable information or incompleteness were excluded, the statistical model still indicated a statistically significant disparity between white and minority approval rates. The results from this regression are presented in Table $10 .^{23}$ The continuing significance of the minority dummy variable suggests that unverified and incomplete loan files alone cannot explain the disparity between white and minority denial rates. A detailed examination however, indicated that there were further factors contributing to denial that were not included in the statistical model for most of the rejected applications. ${ }^{24}$

The most frequent such factor was the presence of one or more open collection items on an applicant's credit report. The statistical analysis did not distinguish between paid and unpaid

\footnotetext{
${ }^{22}$ Note that the large and significant coefficient on Broker in this regression only reflects the time spent on these applications by the bank; any time spent by the broker collecting the information contained in the loan file prior to its presentation to the bank cannot be measured by examiners.

${ }^{23}$ Again, the results were robust to performing a multinomial logistic regression incorporating each of the possible outcomes: approvals, denials due to unverifiable information or incompleteness, and other denials.

${ }^{24}$ There were two rejected loan applications that contained no additional information outside that incorporated into the statistical model. In both of these cases, the predicted probability of approval was very low because of a number of derogatory factors. Thus, the model fully explained these rejections.
} 
collections because this information had not been collected. ${ }^{25}$ If the information had been collected, then it may have been feasible to determine whether the presence of an open collection item meant certain rejection or to control for this factor in a statistical model. Instead, examiners relied on a judgmental analysis to determine whether this reason for rejection had been applied in a non-discriminatory manner.

Other factors contributing to denial appeared to be more idiosyncratic in nature. These included, for instance, reliance on rental income coupled with a very-high back-end ratio, and issues pertaining to the adequacy of the collateral coupled with a high loan-to-value ratio. Such factors, because they are unusual, cannot feasibly be controlled for in a statistical model. Again, examiners relied on a judgmental analysis to determine whether these reasons for rejection had been applied in a non-discriminatory manner.

\section{The Uses and Limitations of Statistics}

The recent use of statistical techniques in compliance examinations has not been without its critics. ${ }^{26}$ In this section, we highlight some of the more important concerns that have been raised about the use of statistics to detect discrimination in the mortgage underwriting process, and explain how the overall fair lending examination process overcomes some of these problems.

\subsection{Combining Institutions, Products, and Markets}

One of the more fundamental concerns with interpreting the Boston Fed Study's results is their use of multiple institutions with different underwriting guidelines. Similarly, many have expressed concerns about combining applications from different loan programs and different markets, even when only one institution's lending practices are analyzed.

Obviously, the banking regulatory agencies analyze each institution independently for fair-lending compliance. Furthermore, each product type is analyzed in isolation, to ensure that any differences in underwriting practices across product types do not bias the statistical results.

\footnotetext{
${ }^{25}$ Collecting data from loan applications, particularly from applicant credit reports, is a time-consuming and painstaking process. As discussed above, to conserve resources examiners limit the collection based on a review of the bank's lending policies, discussions with bank credit officers, and prior experience.

${ }^{26}$ Rachlis (1995) provides a nice summary of these criticisms. See also Phillips and Trost (1995).
} 
Examiners' ability to directly inspect loan files allows them to separate applications belonging to product sub-categories that are characterized by substantially different underwriting. For example, applications for special loan programs are always analyzed separately from those for the bank's conventional loan products. Finally, examiners at the Federal Reserve analyze markets individually, except when there is a compelling reason to combine observations from different markets. ${ }^{27}$

\subsection{Data Problems}

The second class of concerns about the use of statistics in detecting discrimination revolves around the reliability of the data used. Unlike the Boston Fed researchers, compliance examiners are able to collect their data directly from each of the loan files in their sample. Furthermore, if there are questions about the interpretation of some information in the loan file (e.g., whether gift funds should be included as liquid assets), they are often able to speak personally with the loan officer or underwriter who processed the loan. As a result, odd or hardto-interpret data are rarely a problem in bank-specific exams.

A specific concern lies in determining which loans should be counted as accepted and which as rejected. For example, if an applicant fails to provide employment contact information so that the bank cannot verify income or employment, the loan will likely be rejected. At the same time, this failure to provide this information may reflect an applicant who has implicitly decided to withdraw his or her application. Whether such an application should be coded as rejected or withdrawn is a difficult call. Once again, however, examiners' ability to manually inspect the loan files and speak personally with the bank's staff makes it possible for these cases to be interpreted in a consistent way, or for them to be identified and excluded from the statistical analysis. $^{28}$

\footnotetext{
${ }^{27}$ For example, markets will be combined to obtain a sample of sufficient size, but only if the underwriting decisions for these markets are made at a single office and are based on a uniform set of guidelines. We are not familiar with other agencies' policies regarding the combining of markets for a statistical analysis.

${ }^{28}$ When they are excluded from the statistical portion of the exam, examiners will typically give such applications a careful independent review.
} 


\subsection{Specification Problems}

A third problem often cited with the Boston Fed study and other statistical tests of mortgage discrimination is the specification of the statistical model. In particular, many researchers have criticized the underwriting variables used by Munnell, et al. as being incomplete or inconsistent. As discussed above, examiners choose the data to collect based on their conversations with the bank's loan officers and loan review committee. Thus, there is every reason to believe that they collect those variables that are most important to the bank's underwriting decisions. Furthermore, because examiners collect very detailed information from the loan files, a large number of different model specifications may be tried, to ensure the best statistical fit and to verify the robustness of the statistical results. Finally, examiners are able to follow up the statistical analysis with a review of individual loan files. On occasion, this analysis reveals variables that should have been included in the statistical model. Although such variables often cannot be included in the model at this point, examiners are able to use their judgement to ensure that the factor was applied without bias.

\subsection{Modeling the Underwriting Process}

Perhaps the most strident criticism of the use of statistics to uncover discrimination has been over the proper way to model the application and underwriting decisions. ${ }^{29}$ Most empirical work to date has applied single-equation estimation techniques, focusing on the underwriting decision independent of the application decision. In contrast, it is argued that pre-screening or self-selection processes may influence the composition of the applicant pool as well as the eventual underwriting decision, and that failure to model such processes may bias the estimated coefficients of the underwriting decision model or cloud the interpretation of the results. In particular, if white individuals who are likely to be rejected are more apt to self-select out of the applicant pool than comparable minorities, then the single-equation model may provide a false indication of discrimination.

This criticism is muted in the fair lending examination context in part because the

\footnotetext{
${ }^{29}$ There has been relatively little theoretical work on this problem; a notable exception is Longhofer and Peters (2000). As a consequence, structural models are rarely used in empirical work in this area.
} 
purpose of a compliance examination is quite distinct from that of a more general econometric study. As Stengel and Glennon (1999) effectively argue, the goal in a fair-lending exam is to determine whether the bank's stated underwriting guidelines are applied without bias with respect to an applicant's race or other protected characteristic. The statistical component of this exam is intended to 'develop a bank-specific model that represents the underwriters' decision rule ... as it was applied against the bank's own applicant pool." 30

This criticism is further muted by consideration of the role of the follow-up file review in the examination process. If there is a credit characteristic omitted from the statistical model that may have induced some white potential applicants to self-select out of the sample and that was a cause for rejection of a number of minority applications, then this characteristic may be identified during the file reviews.

A more relevant concern is that underwriting may be a multi-step process, in which new data collected about an individual may depend on the characteristics of data already collected. For example, if an applicant's credit report shows sufficiently severe blemishes to merit rejection, then the applicant's income may never be verified. This raises concern about the quality of the data used in the analysis, particularly among rejected loan files.

The discussion in the last section showed that unverified information or incomplete applications played a large part in the decision to reject some applications. It is exactly this problem that makes follow-up file review such an important part of the whole examination process. By looking at individual loan files, examiners can ascertain the degree to which their statistical results may be biased by the underwriting process itself. In the end, informed examiner judgement must be the final arbiter in interpreting the results of any statistical model.

\section{Conclusions}

The use of statistical analysis for detecting discrimination in mortgage lending has been criticized on the grounds that the potential for data recording errors and problems of model specification raise the potential for such an evaluation to lead to an inappropriate conclusion.

\footnotetext{
${ }^{30}$ Stengel and Glennon (1999), p. 304.
} 
Moreover, conducting a logistic regression analysis of an institution's application approval patterns is costly and requires a major commitment of examiner resources, which would seem to be justifiable only if the results are likely to be reliable.

This case study demonstrates that potential difficulties related to the statistical analysis of mortgage lending decisions can contribute to inappropriate conclusions if the statistical results are taken at face value. A statistically significant relationship was found between minority status and likelihood of denial in a logistic regression equation where each of the major factors in the institution's underwriting policies as interpreted or understood by examiners were controlled for. The empirical model also controlled for conditions not explicitly related to underwriting policies that might affect the disposition of an application; namely, the season when it was filed and whether the loan application was processed and submitted by a mortgage broker. Moreover, a very broad data collection effort was undertaken for the analysis, and the finding was robust to alternative model specifications. Ultimately, however, this finding was attributed to a possible omitted variable (unpaid collections) and to factors that are not amenable to statistical modeling. The latter included incomplete or unverifiable information in the file and idiosyncratic factors specific to individual applications, such as property deficiencies.

Nevertheless, as this study illustrates, statistical tools have a useful role to play within the full compliance examination context. Initial statistical analysis using HMDA data is a costeffective way to screen institutions before examiner resources are committed to conducting a logistic regression analysis. Institutions that do not exhibit substantial disparities in their HMDA-reported data (and those that would not provide a sample of adequate size and composition) are not subject to further statistical review but undergo more traditional, judgmental review by examiners. When a logistic regression analysis is undertaken, the results provide examiners with important information regarding the extent to which a disparity persists once major underwriting variables are taken into consideration, enhancing their ability to detect a pattern of discriminatory treatment. Further, the logistic regression procedure enables examiners to separate out the effects of major underwriting variables and focus their investigation on other factors, including possible discrimination, that might have contributed to an observed disparity. 
Finally, the direct examination of loan files that follows the statistical investigation helps ensure that the ultimate causes of an observed disparity will be identified. There is little reason to believe that an examination process that incorporates statistical analysis along with judgmental review would be more apt to result in an inappropriate referral than a purely judgmental exam. Statistical analysis in combination with comparative file review appears to provide a balanced and thorough approach to enforcement of fair-lending laws. 


\section{Tables}

\section{Table 1}

Step-one Analysis

Nationwide HMDA Data

\begin{tabular}{|l|c|c|c|}
\hline \multicolumn{1}{|c|}{ Loan Class } & $\begin{array}{c}\text { Paired } \\
\text { Minority } \\
\text { Denial Rate }\end{array}$ & $\begin{array}{c}\text { Paired } \\
\text { White } \\
\text { Denial Rate }\end{array}$ & $\begin{array}{c}\text { Paired } \\
\text { Denial-rate } \\
\text { Disparity }\end{array}$ \\
\hline Overall & $16.9 \%$ & $11.3 \%$ & $5.6 \% * * *$ \\
\hline Conventional Purchase & $15.7 \%$ & $10.7 \%$ & $5.0 \% * * *$ \\
\hline Conventional Refinance & $19.1 \%$ & $12.6 \%$ & $6.5 \% * * *$ \\
\hline FHA/VA Purchase & $19.9 \%$ & $13.0 \%$ & $6.9 \% * * *$ \\
\hline FHA/VA Refinance & $40.0 \%$ & $8.1 \%$ & $31.9 \% *$ \\
\hline
\end{tabular}

*** Denial-rate disparities significant at the $1 \%$ level.

** Denial-rate disparities significant at the 5\% level.

* Denial-rate disparities significant at the $10 \%$ level.

Note: The disparities among FHA/VA refinancings are less significant due to the small number of such loans processed by this institution. 


\section{Table 2}

Step-one Analysis

Nationwide HMDA Data by Race

\begin{tabular}{|l|c|c|c|}
\hline \multicolumn{1}{|c|}{ Minority Group } & $\begin{array}{c}\text { Paired } \\
\text { Minority } \\
\text { Denial Rate }\end{array}$ & $\begin{array}{c}\text { Paired } \\
\text { White } \\
\text { Denial Rate }\end{array}$ & $\begin{array}{c}\text { Paired } \\
\text { Denial-rate } \\
\text { Disparity }\end{array}$ \\
\hline All minority & $16.9 \%$ & $11.3 \%$ & $5.6 \% * * *$ \\
\hline American Indian & $16.9 \%$ & $9.7 \%$ & $7.2 \%$ \\
\hline Asian & $12.0 \%$ & $8.8 \%$ & $3.2 \%$ \\
\hline Black & $19.8 \%$ & $10.9 \%$ & $8.9 \% * * *$ \\
\hline Hispanic & $16.1 \%$ & $12.9 \%$ & $3.2 \% * * *$ \\
\hline
\end{tabular}

*** Denial-rate disparities significant at the $1 \%$ level.

** Denial-rate disparities significant at the 5\% level.

* Denial-rate disparities significant at the $10 \%$ level. 


\section{Table 3}

Step-one Analysis

HMDA Denial Rates by Product Type

Target MSA

\begin{tabular}{|l|c|c|c||}
\hline \multicolumn{1}{|c|}{ Loan Class } & $\begin{array}{c}\text { Paired } \\
\text { Minority } \\
\text { Denial Rate }\end{array}$ & $\begin{array}{c}\text { Paired } \\
\text { White } \\
\text { Denial Rate }\end{array}$ & $\begin{array}{c}\text { Paired } \\
\text { Denial-rate } \\
\text { Disparity }\end{array}$ \\
\hline \hline Overall & $21.0 \%$ & $13.6 \%$ & $7.4 \% * * *$ \\
\hline Conventional Purchase & $17.3 \%$ & $8.4 \%$ & $8.9 \% * * *$ \\
\hline Government Purchase & $26.3 \%$ & $20.8 \%$ & $5.5 \%$ \\
\hline Conventional Refinance & $24.5 \%$ & $19.1 \%$ & $5.4 \%$ \\
\hline Government Refinance & $14.3 \%$ & $11.7 \%$ & $2.6 \%$ \\
\hline \hline
\end{tabular}

*** Denial-rate disparities significant at the $1 \%$ level.

$* *$ Denial-rate disparities significant at the 5\% level.

* Denial-rate disparities significant at the $10 \%$ level. 


\section{Table 4}

\section{Step Two Variable Definitions}

\begin{tabular}{|c|c|}
\hline Variable & Definition \\
\hline Accept & $\begin{array}{ll}1 & \text { if the loan was accepted } \\
0 & \text { if the loan was rejected }\end{array}$ \\
\hline Back1 & $\begin{array}{ll}1 & \text { if } 40 \% \leq \text { back-end ratio }<45 \% \\
0 & \text { otherwise }\end{array}$ \\
\hline Back2 & $\begin{array}{ll}1 & \text { if back-end ratio } \geq 45 \% \\
0 & \text { otherwise }\end{array}$ \\
\hline Bankruptcy & 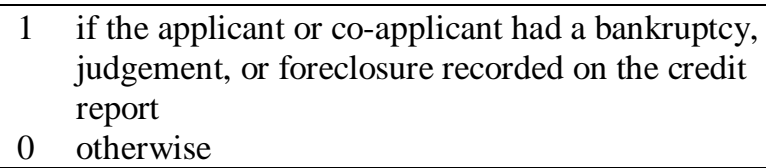 \\
\hline Broker & $\begin{array}{ll}1 & \text { if application was processed by a broker } \\
0 & \text { if application was processed by an internal loan } \\
\text { officer }\end{array}$ \\
\hline Co-applicant & $\begin{array}{ll}1 & \text { if a co-applicant was present } \\
0 & \text { if there was only one applicant }\end{array}$ \\
\hline Deficit & $\begin{array}{ll}1 & \text { if the applicant had insufficient liquid assets to } \\
\text { close the loan } \\
0 \\
\text { if the applicant's liquid assets was greater than } \\
\text { the cash required to close }\end{array}$ \\
\hline Income & Combined applicant and co-applicant annual income \\
\hline Liquid & $\begin{array}{ll}1 & \begin{array}{l}\text { if liquid assets were more than twice that } \\
\text { required to close the loan } \\
\text { otherwise }\end{array} \\
\end{array}$ \\
\hline LTVGT80 & $\begin{array}{ll}1 & \text { if loan-to-value ratio }>80 \% \\
0 & \text { if loan-to-value ratio } \leq 80 \%\end{array}$ \\
\hline Minority & $\begin{array}{l}1 \text { if either the applicant or the co-applicant was a } \\
\text { minority } \\
0 \text { if both the applicant and co-applicant were white }\end{array}$ \\
\hline Retired & $\begin{array}{ll}1 & \text { if the applicant was retired } \\
0 & \text { otherwise }\end{array}$ \\
\hline Spring & $\begin{array}{l}1 \text { If the application was received during the second } \\
\text { quarter of the year } \\
0 \quad \text { otherwise }\end{array}$ \\
\hline Summer & $\begin{array}{ll}1 & \begin{array}{l}\text { If the application was received during the third } \\
\text { quarter of the year }\end{array} \\
0 & \text { otherwise }\end{array}$ \\
\hline Stable Income & $\begin{array}{ll}1 & \text { If both applicants had been working in their } \\
\text { current jobs for at least } 3 \text { years } \\
\text { otherwise }\end{array}$ \\
\hline Winter & $\begin{array}{ll}1 & \text { If the application was received during the first } \\
& \text { quarter of the year } \\
0 & \text { otherwise }\end{array}$ \\
\hline
\end{tabular}


Table 5

Descriptive Statistics of

Variables Used in the Analysis

\begin{tabular}{|l|c|c|c|c||}
\hline \multicolumn{1}{|c|}{ Variable } & Mean & $\begin{array}{c}\text { Standard } \\
\text { Deviation }\end{array}$ & Minimum & Maximum \\
\hline Accept & 0.8735 & 0.3329 & 0 & 1 \\
\hline Back1 & 0.0941 & 0.2924 & 0 & 1 \\
\hline Back2 & 0.0529 & 0.2243 & 0 & 1 \\
\hline Bankruptcy & 0.2441 & 0.4302 & 0 & 1 \\
\hline Broker & 0.4794 & 0.5003 & 0 & 1 \\
\hline Co-applicant & 0.7000 & 0.4589 & 0 & 1 \\
\hline Deficit & 0.0500 & 0.2183 & 0 & 1 \\
\hline Income & 47.9559 & 27.9901 & 13 & 197 \\
\hline Liquid & 0.5294 & 0.4999 & 0 & 1 \\
\hline LTVGT80 & 0.5441 & 0.4988 & 0 & 1 \\
\hline Minority & 0.4529 & 0.4985 & 0 & 1 \\
\hline Retired & 0.2029 & 0.4028 & 0 & 1 \\
\hline Spring & 0.2559 & 0.4370 & 0 & 1 \\
\hline Summer & 0.2647 & 0.4418 & 0 & 1 \\
\hline Stable Income & 0.3677 & 0.4829 & 0 & 1 \\
\hline Winter & 0.1382 & 0.3457 & 0 & 1 \\
\hline \hline
\end{tabular}




\section{Table 6}

Final Logistic Regression Results

Dependent Variable: Accept

\begin{tabular}{|l|r|c|c|c||}
\hline \multicolumn{1}{|c|}{ Variable } & $\begin{array}{c}\text { Parameter } \\
\text { Estimate }\end{array}$ & $\begin{array}{c}\text { Standard } \\
\text { Error }\end{array}$ & P-Value & $\begin{array}{c}\text { Percentage } \\
\text { Impact }\end{array}$ \\
\hline Intercept & 3.2496 & 0.8524 & 0.0001 & \\
\hline Back1 & -1.5129 & 0.6149 & 0.0139 & $-8.27 \%$ \\
\hline Back2 & -2.6880 & 0.7546 & 0.0004 & $-25.75 \%$ \\
\hline Bankruptcy & -1.0574 & 0.4548 & 0.0201 & $-4.57 \%$ \\
\hline Broker & 1.4339 & 0.4774 & 0.0027 & $1.99 \%$ \\
\hline Co-applicant & 0.3973 & 0.5495 & 0.4697 & $0.84 \%$ \\
\hline Deficit & -1.2276 & 0.7215 & 0.0889 & $-5.80 \%$ \\
\hline Income & 0.0076 & 0.0091 & 0.4032 & $0.02 \%$ \\
\hline Liquid & 1.0793 & 0.4804 & 0.0246 & $1.72 \%$ \\
\hline LTVGT80 & -1.0558 & 0.5058 & 0.0368 & $-4.56 \%$ \\
\hline Minority & -1.0787 & 0.4581 & 0.0185 & $-4.72 \%$ \\
\hline Retired & 1.1960 & 0.7006 & 0.0878 & $1.82 \%$ \\
\hline Spring & -2.6738 & 0.6504 & 0.0001 & $-25.46 \%$ \\
\hline Summer & -1.8274 & 0.6711 & 0.0065 & $-11.72 \%$ \\
\hline Stable Income & 1.8708 & 0.5873 & 0.0014 & $2.21 \%$ \\
\hline Winter & -1.0326 & 0.8228 & 0.2094 & $-4.41 \%$ \\
\hline \hline
\end{tabular}

Note: The base case is an applicant for whom all dummy variables are equal to zero with an income at the sample mean $(\$ 47,956)$. Such an applicant has a $97.38 \%$ probability of being approved. The "percentage impact" measures the change in the probability of being approved if the variable is changed from 0 to 1 (or if income is increased by $\$ 1,000$ ). Thus, an average income applicant with a bankruptcy, garnishment, or judgement on his credit report (Bankrupt $=$ 1) has a $92.80 \%$ chance of being approved, assuming all other dummy variables are equal to zero. 


\section{Table 7}

Follow-up File Review

Summary of Reasons for Denial

\begin{tabular}{|c|c|c|c|c|c|c|c|c|}
\hline No. & Race & Broker & $\begin{array}{c}\text { Likelihood } \\
\text { of } \\
\text { Approval }\end{array}$ & Verification Issues & $L T V$ & $\begin{array}{c}\text { Back-end } \\
\text { Ratio }\end{array}$ & $\begin{array}{c}\text { Credit } \\
\text { History }^{1}\end{array}$ & $\begin{array}{l}\text { Collateral or } \\
\text { Other Issues }\end{array}$ \\
\hline 1 & Minority & & 0.997 & $\begin{array}{l}\text { Unverified items (details } \\
\text { not available) }\end{array}$ & & & & \\
\hline 2 & White & Yes & 0.98 & $\begin{array}{l}\text { Unverified items (details } \\
\text { not available) }\end{array}$ & & & & \\
\hline 3 & Minority & & 0.97 & & & & Poor & \\
\hline 4 & Minority & Yes & 0.96 & Liquid assets & $>80$ & & & $\begin{array}{l}\text { No credit or } \\
\text { rental history }\end{array}$ \\
\hline 5 & White & & 0.95 & $\begin{array}{l}\text { Incomplete application } \\
\text { (details not available) }\end{array}$ & & & & \\
\hline 6 & White & & 0.95 & & & & Poor & $\begin{array}{l}\text { Open } \\
\text { collections }\end{array}$ \\
\hline 7 & Minority & & 0.95 & $\begin{array}{l}\text { Incomplete application } \\
\text { (various) }^{3}\end{array}$ & $>80$ & & & \\
\hline 8 & Minority & & 0.94 & & $>80$ & & & Collateral $^{4}$ \\
\hline 9 & Minority & & 0.94 & & $>80$ & & & Collateral $^{5}$ \\
\hline 10 & Minority & Yes & 0.93 & $\begin{array}{l}\text { Incomplete application } \\
\text { (details not available) }\end{array}$ & $>80$ & & & \\
\hline 11 & Minority & Yes & 0.93 & $\begin{array}{l}\text { Incomplete application } \\
\text { (coap. credit report) }\end{array}$ & $>80$ & & & \\
\hline 12 & Minority & & 0.92 & $\begin{array}{l}\text { Incomplete (details not } \\
\text { available) }\end{array}$ & & & & $\begin{array}{l}\text { Mobile home } \\
\text { transaction }^{6}\end{array}$ \\
\hline 13 & Minority & Yes & 0.87 & $\begin{array}{l}\text { Unverified items (details } \\
\text { not available) }\end{array}$ & $>80$ & & Poor & \\
\hline 14 & White & Yes & 0.84 & & $>80$ & $40-44$ & & \\
\hline 15 & Minority & Yes & 0.82 & $\begin{array}{l}\text { Unverified items (details } \\
\text { not available) }\end{array}$ & $>80$ & & Poor & $\begin{array}{l}\text { No } \\
\text { employment } \\
\text { history }{ }^{7}\end{array}$ \\
\hline 16 & White & & 0.75 & & $>80$ & & & Collateral $^{8}$ \\
\hline 17 & Minority & Yes & 0.74 & $\begin{array}{l}\text { Liquid assets, work } \\
\text { history }\end{array}$ & & $40-44$ & & \\
\hline 18 & Minority & & 0.74 & & $>80$ & $40-44$ & Poor & $\begin{array}{l}\text { Open } \\
\text { collections }\end{array}$ \\
\hline 19 & Minority & Yes & 0.74 & Liquid assets & $>80$ & & & \\
\hline 20 & White & & 0.72 & Income & $>80$ & $40-44$ & & Collateral $^{9}$ \\
\hline
\end{tabular}

\footnotetext{
${ }^{1}$ Poor credit history refers to a credit record exhibiting a bankruptcy, foreclosure, collection, judgment, or garnishment.

2 The applicants were recent immigrants.

${ }^{3}$ Required documentation not in the file included a contract for new construction and a gift letter.

${ }_{5}^{4}$ The property was a condo in a building with a high vacancy rate.

5 The property was appraised "as is." Denial of private mortgage insurance also was listed as a reason for rejection of the application.

${ }^{6}$ The applicant was seeking to finance the purchase of a site and the cost of moving the mobile home.

7 The applicants were recent graduates.

${ }^{8}$ The property was a condo in a building with a high vacancy rate. Denial of private mortgage insurance also was listed as a reason for rejection of the application.

${ }^{9}$ FNMA guidelines for adjustments against comparable properties were exceeded.
} 


\begin{tabular}{|c|c|c|c|c|c|c|c|c|}
\hline No. & Race & Broker & $\begin{array}{c}\text { Likelihood } \\
\text { of } \\
\text { Approval }\end{array}$ & Verification Issues & $L T V$ & $\begin{array}{c}\text { Back-end } \\
\text { Ratio }\end{array}$ & $\begin{array}{c}\text { Credit } \\
\text { History }^{10}\end{array}$ & $\begin{array}{l}\text { Collateral or } \\
\text { Other Issues }\end{array}$ \\
\hline 21 & Minority & Yes & 0.71 & Income & $>80$ & & Poor & \\
\hline 22 & White & Yes & 0.68 & & & $>44$ & & \\
\hline 23 & Minority & & 0.66 & & $>80$ & & Poor & $\begin{array}{l}\text { Current } \\
\text { delinquency }\end{array}$ \\
\hline 24 & Minority & Yes & 0.64 & Income & & $>44$ & Poor & $\begin{array}{l}\text { Subordinate } \\
\text { financing }{ }^{11}\end{array}$ \\
\hline 25 & White & Yes & 0.62 & Income, liquid assets & $>80$ & & Poor & \\
\hline 26 & Minority & & 0.62 & & $>80$ & $40-44$ & & \\
\hline 27 & Minority & & 0.59 & $\begin{array}{l}\text { Incomplete application } \\
\text { (details not available) }\end{array}$ & $>80$ & & & \\
\hline 28 & Minority & Yes & 0.56 & $\begin{array}{l}\text { Incomplete application } \\
\text { (details not available) }\end{array}$ & $>80$ & & Poor & \\
\hline 29 & Minority & & 0.52 & & & & Poor & $\begin{array}{l}\text { Open } \\
\text { collections }\end{array}$ \\
\hline 30 & Minority & & 0.50 & & $>80$ & & Poor & $\begin{array}{l}\text { Open } \\
\text { collections }\end{array}$ \\
\hline 31 & White & & 0.44 & & & $40-44$ & Poor & \\
\hline 32 & Minority & & 0.43 & & $>80$ & $>44$ & & $\begin{array}{l}\text { Rental } \\
\text { income }\end{array}$ \\
\hline 33 & White & & 0.43 & $\begin{array}{l}\text { Incomplete application } \\
\text { (funds-to-close) }\end{array}$ & $>80$ & & Poor & \\
\hline 34 & Minority & & 0.40 & & & $>44$ & & $\begin{array}{l}\text { File remained } \\
\text { open }^{12}\end{array}$ \\
\hline 35 & Minority & & 0.36 & & $>80$ & $>44$ & Poor & $\begin{array}{l}\text { Open } \\
\text { collection, } \\
\text { collateral }^{13}\end{array}$ \\
\hline 36 & White & & 0.33 & & $>80$ & $>44$ & & $\begin{array}{l}\text { Rental } \\
\text { income }\end{array}$ \\
\hline 37 & White & & 0.26 & & $>80$ & $40-44$ & Poor & $\begin{array}{l}\text { Current } \\
\text { delinquency }\end{array}$ \\
\hline 38 & Minority & & 0.18 & & $>80$ & $>44$ & & \\
\hline 39 & White & & 0.11 & Liquid assets & $>80$ & & Poor & \\
\hline 40 & Minority & & 0.07 & & $>80$ & $>44$ & Poor & \\
\hline 41 & Minority & & 0.07 & & $>80$ & $40-44$ & Poor & \\
\hline 42 & Minority & & 0.05 & & $>80$ & $>44$ & Poor & \\
\hline 43 & Minority & & 0.02 & & $>80$ & $>44$ & Poor & $\begin{array}{l}\text { Open } \\
\text { collections }\end{array}$ \\
\hline
\end{tabular}

\footnotetext{
${ }^{10}$ Poor credit history refers to a credit record exhibiting a bankruptcy, foreclosure, collection, judgment, or garnishment.

11 The application exceeded the bank's minimum loan-to-value ratio guideline for a loan with 10 percent subordinate financing.

12 The denial was tied to insufficient funds to close and a high back-end ratio resulting from current ownership of a home. The file was to remain open for 90 days pending an agreement for sale of the home.

${ }^{13}$ Severe property deficiencies, including zoning problems, were present.
} 


\section{Table 8}

Likelihood of Approval Restricting Attention to Denials Due to Incomplete/Unverifiable Information Logistic Regression Results Dependent Variable: Accept

\begin{tabular}{|l|c|c|c|c||}
\hline \multicolumn{1}{|c|}{ Variable } & $\begin{array}{c}\text { Parameter } \\
\text { Estimate }\end{array}$ & $\begin{array}{c}\text { Standard } \\
\text { Error }\end{array}$ & P-Value & $\begin{array}{c}\text { Percentage } \\
\text { Impact }\end{array}$ \\
\hline Intercept & 4.1653 & 0.7597 & 0.0001 & \\
\hline Bankruptcy & -1.0686 & 0.5771 & 0.0641 & $-2.80 \%$ \\
\hline Broker & -0.2854 & 0.5318 & 0.5915 & $-0.49 \%$ \\
\hline Deficit & -1.5036 & 0.7809 & 0.0542 & $-5.00 \%$ \\
\hline Liquid & 1.5159 & 0.6232 & 0.0150 & $1.19 \%$ \\
\hline Minority & -1.3354 & 0.5648 & 0.0181 & $-4.04 \%$ \\
\hline Spring-or-Summer & -1.5780 & 0.6178 & 0.0106 & $-5.47 \%$ \\
\hline Stable Income & 1.4272 & 0.6914 & 0.0390 & $1.16 \%$ \\
\hline
\end{tabular}

Notes: This regression excludes applications that were rejected for reasons other than incomplete or unverifiable information, leaving a sample size of 317 applications. Spring-orSummer is a dummy variable that takes the value of 1 if the application was made during the $2^{\text {nd }}$ or $3^{\text {rd }}$ quarters of the year. The percentage impacts are calculated as in Table 6 . The "base case" probability of being approved is $98.47 \%$. 


\section{Table 9}

Processing Time for Denials Due to Incomplete/Unverifiable Information

OLS Regression Results

Dependent Variable: Days between Application Date and Action Date

\begin{tabular}{|l|c|c|c||}
\hline \multicolumn{1}{|c|}{ Variable } & $\begin{array}{c}\text { Parameter } \\
\text { Estimate }\end{array}$ & $\begin{array}{c}\text { Standard } \\
\text { Error }\end{array}$ & P-Value \\
\hline Intercept & 74.1441 & 19.1607 & 0.0014 \\
\hline Broker & -36.8220 & 13.4371 & 0.0145 \\
\hline Minority & 5.5170 & 15.1230 & 0.7200 \\
\hline Spring-or-Summer & -24.2034 & 16.2732 & 0.1564 \\
\hline
\end{tabular}

Notes: This regression used the 20 observations that were rejected because of incomplete or unverifiable information. Spring-or-Summer is a dummy variable that takes the value of 1 if the application was made during the $2^{\text {nd }}$ or $3^{\text {rd }}$ quarters of the year. 
Table 10

Analysis of Direct Loans - Incomplete Loan Files Excluded

Logistic Regression Results

Dependent Variable: Accept

\begin{tabular}{|l|c|c|c|c||}
\hline \multicolumn{1}{|c|}{ Variable } & $\begin{array}{c}\text { Parameter } \\
\text { Estimate }\end{array}$ & $\begin{array}{c}\text { Standard } \\
\text { Error }\end{array}$ & P-Value & $\begin{array}{c}\text { Percentage } \\
\text { Impact }\end{array}$ \\
\hline Intercept & 6.9267 & 1.8945 & 0.0003 & \\
\hline Back-end Ratio & -0.1000 & 0.0386 & 0.0096 & $0.00 \%$ \\
\hline Bankruptcy & -1.9236 & 0.7155 & 0.0072 & $-0.22 \%$ \\
\hline Co-applicant & 1.0998 & 0.8937 & 0.2184 & $0.03 \%$ \\
\hline Deficit & -2.6749 & 1.5099 & 0.0765 & $-0.51 \%$ \\
\hline Income & 0.0197 & 0.0156 & 0.2057 & $0.00 \%$ \\
\hline Liquid & 0.2646 & 0.7192 & 0.7129 & $0.01 \%$ \\
\hline LTVGT80 & -1.6225 & 0.8598 & 0.0592 & $-0.15 \%$ \\
\hline Minority & -1.5316 & 0.7698 & 0.0466 & $-0.14 \%$ \\
\hline Retired & 2.3625 & 1.2948 & 0.0681 & $0.03 \%$ \\
\hline Spring-or-Summer & -2.3903 & 0.8215 & 0.0036 & $-0.38 \%$ \\
\hline Stable Income & 1.9464 & 1.0348 & 0.0600 & $0.03 \%$ \\
\hline \hline
\end{tabular}

Notes: This regression excluded all brokered loans and those files that were rejected because of incomplete or unverified information. This left a final sample size of 169. Because of the reduced number of rejected loan files in the sample, the specification excludes some variables incorporated in the original analysis. Spring-or-Summer is a dummy variable that takes the value of 1 if the application was made during the $2^{\text {nd }}$ or $3^{\text {rd }}$ quarters of the year. Back-end Ratio is the total debt obligation ratio presented as a continuous variable. The "base case" probability of being approved is $96.96 \%$. 


\section{References}

Avery, Robert B., Patricia E. Beeson, and Paul S. Calem. "Using HMDA Data as a Regulatory Screen for Fair Lending Compliance." Journal of Financial Services Research, vol. 11, no. 1/2, February/April 1997, pp. 9-42.

Bostic, Raphael W. "The Role of Race in Mortgage Lending: Revisiting the Boston Fed Study." Board of Governors of the Federal Reserve System, unpublished manuscript, December 1996.

Browne, Lynn Elaine and Geoffrey M.B. Tootell. "Mortgage Lending in Boston-A Response to the Critics." New England Economic Review, September/October 1995, p. 53.

Calem, Paul S. and Glenn B. Canner. "Integrating Statistical Analysis into Fair-Lending Exams: The Fed's Approach," in Fair Lending Analysis: A Compendium of Essays on the Use of Statistics, Anthony M. Yezer, ed. American Bankers Association: Washington, DC. 1995.

Carr, James H. and Isaac F. Megbolugbe. "The Federal Reserve Bank of Boston Study on Mortgage Lending Revisited." Journal of Housing Research, vol. 4, no. 2, 1993, pp. 277-313.

Day, Ted and Stan J. Leibowitz. "Mortgage Lending to Minorities: Where's the Bias." Economic Inquiry, vol. 34, January 1998, pp. 3-28.

Galster, George C. "The Facts of Lending Discrimination Cannot be Argued away by Examining Default Rates.” Housing Policy Debate, vol. 4, 1993, p. 141.

Glennon, Dennis and Stengel Mitchell. “An Evaluation of the Federal Reserve Bank of Boston's Study of Racial Discrimination in Mortgage Lending." Economic and Policy Analysis Working Paper 94-2, Office of the Comptroller of the Currency, April 1994.

Golan, Amos, Marsha Courchane, and David Nickerson. "An Informational Based Estimation Method Reveals Evidence of Loan Discrimination.” American University, unpublished manuscript, 1999.

Horne, David K. "Mortgage Lending, Race, and Model Specification." Journal of Financial Services Research, vol. 11, nos. 1/2, February/April 1997, pp. 43-68.

Hunter, William C. and Mary Beth Walker. "The Cultural Gap Hypothesis and Mortgage Lending Decisions." Journal of Real Estate Finance and Economics, vol. 13, no. 1, July 1996, pp. 57-70.

Longhofer, Stanley D. and Stephen R. Peters. "Why is Mortgage Discrimination Illegal? A Fresh Look at the Mortgage Discrimination Debate." Regulation, Cato Institute, vol. 22, no. 4, 1999, pp. 28-36. 
Longhofer, Stanley D. and Stephen R. Peters. "Self-selection and Discrimination in Credit Markets." Federal Reserve Bank of Cleveland, Working Paper No. 9809, January 2000.

Munnell, Alicia H., Lynn E. Browne, James McEneaney, and Geoffrey M.B. Tootell. "Mortgage Lending in Boston: Interpreting HMDA Data." Federal Reserve Bank of Boston Working Paper No. 92-7, October 1992.

Munnell, Alicia H., Geoffrey M.B. Tootell, Lynn E. Browne, and James McEneaney. "Mortgage Lending in Boston: Interpreting HMDA Data." American Economic Review, vol. 86, no. 1, March 1996, pp. 25-53.

Phillips, Robert F. and Robert P. Trost. "Can Statistical Problems in Tests for Lending Discrimination be Resolved?" in Fair Lending Analysis: A Compendium of Essays on the Use of Statistics, Anthony M. Yezer, ed. American Bankers Association: Washington, DC. 1995.

Rachlis, Mitchell B. "Nine Common Flaws Found in Statistical Models of the Loan Approval Process," in Fair Lending Analysis: A Compendium of Essays on the Use of Statistics, Anthony M. Yezer, ed. American Bankers Association: Washington, DC. 1995.

Rosenblatt, Eric. "A Reconsideration of Discrimination in Mortgage Underwriting with Data from a National Mortgage Bank.” Journal of Financial Services Research, vol. 11, 1997, pp. 109-131.

Sandler, Andrew L. and Jonathan Biran. "The Improper Use of Statistics in Mortgage Lending Discrimination Actions," in Fair Lending Analysis: A Compendium of Essays on the Use of Statistics, Anthony M. Yezer, ed. American Bankers Association: Washington, DC, 1995.

Siskin, Bernard R. and Leonard A. Cupingood. "Use of Statistical Models to Provide Statistical Evidence in Discrimination in the Treatment of Mortgage Loan Applicants: A Study of One Lending Institution," in Mortgage Lending, Racial Discrimination, and Federal Policy, John Goering and Ron Wienk, eds. Urban Institute Press: Washington, DC, 1996, pp. 451- 467.

Stengel, Mitchell and Dennis Glennon. "Evaluating Statistical Models of Mortgage Lending Discrimination: A Bank Specific Analysis." Real Estate Economics, vol. 27, no. 2, Summer 1999, pp. 299-334.

Tootell, Geoffrey M.B. "Defaults, Denials, and Discrimination in Mortgage Lending." New England Economic Review, September/October 1993, pp. 45-51.

Yezer, Anthony M.J., Robert F. Phillips, and Robert P. Trost. "Bias in Estimates of Discrimination and Default in Mortgage Lending: The Effects of Simultaneity and SelfSelection." Journal of Real Estate Finance and Economics, vol. 9, no. 3, 1994, pp. 196215. 